\title{
Study on Evaluation Index of Business Environment from the Perspective of Private Manufacture Enterprises
}

\author{
Cai Liu* ${ }^{*}$ Ke Li \\ Jilin University of Finance and Economics, Changchun, Jilin, 130117 China \\ * Corresponding Author.
}

\begin{abstract}
This paper draws on the research results of the World Bank and domestic and foreign scholars on the business environment and analyzes the development process of private manufacture enterprises in today's society. This paper summarizes the factors that affect the development of business environment and puts forward the evaluation index of business environment from the perspective of private manufacture enterprises.
\end{abstract}

Keywords: Private enterprise, Business environment, Evaluation index, Manufacture

\section{Introduction}

Business involves many subjects and the factors influencing the business environment are complex and diverse. However, the existing business environment assessment index system is not comprehensive enough, and the business environment cannot be evaluated from the perspective of enterprises (especially private manufacture enterprises). Therefore, based on the indicator system from "Doing business 2020 report" released by the world bank and combined with the indicators extracted by the research group from the problems existing in domestic business environment, this paper constructed a relatively comprehensive "business environment assessment index from the perspective of private manufacture enterprises".

\section{The position of private manufacture enterprises in the development of national economy}

Since China's reform and opening up more than 40 years ago, the non-public sector of the economy has developed from scratch, from small to large, and from weak to strong. It is an important part of China's socialist market economy and has become an indispensable force for promoting China's development. Together with the public sector of the economy, they support the great cause of socialism with Chinese characteristics. Employment is the best way to improve people's livelihood. The non-public economy plays an irreplaceable role in promoting employment and serving people's livelihood. At present, the non-public sector accounts for more than $50 \%$ of the total tax revenue, contributes more than $60 \%$ to GDP, accounts for more than $70 \%$ of the achievements of technological innovation and $90 \%$ of the new jobs created by non-public enterprises. This scale fully shows that the non-public sector of the economy plays a huge role in China's economic growth, increasing tax sources, expanding employment and promoting innovation.

\section{Common problems in the development of private manufacture enterprises}

3.1 supporting issues of factor supply.

First, the cost of acquiring factors for private manufacture enterprises is high, that is, the price of land, capital, labor, electricity, water and other factors, as well as the extra cost that private manufacture enterprises need to pay for acquiring these factors. Invisible charge, indirect cost and service lack are common. Although some enterprises have reduced their fees, they have transferred the fees to a third party, which seems to have nothing to do with the 
government and enterprises. In fact, the burden on private manufacture enterprises has not been eased and the production cost of enterprises has increased. In addition, there are still some high fees related to quality inspection, fire production, product inspection, environmental impact assessment and safety assessment. All these fees are monopolistic and there is no price adjustment, which is hard for private manufacture enterprises to afford. Second, the cost of taxes, covering enterprise comprehensive tax cost includes value-added tax, enterprise income tax, urban construction tax, property tax, land use tax, stamp tax, etc. Enterprises need to pay the higher cost of government including educational expenses to add additional, water conservancy construction fund, the local education, the culture construction fee, etc. The VAT deduction rules are too complicated, the responsibility subject is not clear, and the detailed rules of fees charged by some enterprises are not clear, which makes it difficult for private enterprises to enjoy supportive policies.

\subsection{Liquidity of factor resources.}

Private enterprises have poor access to capital. $70 \%$ of private enterprises rely on indirect financing and $30 \%$ rely on direct financing. Indirect financing is mainly for Banks, and most private companies cannot get loans because they need collateral. As stock, bond market of direct financing, the threshold is too high, private enterprise has entered very little. Some small loan companies serving the financing of private enterprises, due to financing difficulties, high risks, heavy tax burden, regulatory dislocation and other problems, their development has been affected.

\subsection{Environmental factors.}

Rule of law environment: the standardization of law enforcement behaviors, including whether administrative departments at all levels perform their duties strictly in accordance with statutory limits and procedures, whether the framework of law enforcement authorities is smooth, whether law enforcement departments adopt uniform standards and whether they treat market subjects fairly. For example, the arbitration system has a large operating space and damages the interests of enterprises. The arbitration committee is composed of a collegial panel of lawyers to handle cases. Although the arbitration law has been promulgated for ten years, it has no detailed rules for the implementation and it is highly operable. In the absence of multi-party interests and the supervision of specific legal departments, the time for handling cases is long and indecisive. This causes damage to the interests of enterprises. Market environment: the unfairness of the market system, private enterprises still encounter many institutional and policy barriers in market access. The transparency of market access still exists the recessive barrier that restricts and restricts the development of non-public economy.

\section{Establishment of business environment assessment indicators from the perspective of private enterprises}

As shown in table 1, this paper constructs two primary indicators and 17 secondary indicators.

\section{1 market convenience:}

Secondary indicators include starting a business, obtaining a construction permit, obtaining electricity, registering property, obtaining credit, protecting minority investors, paying taxes, conducting cross-border trade, enforcing contracts, and going bankrupt and other indicators as listed in the doing business 2020 report. According to enterprise life cycle, eleven indicators were put forward, such as starting a business, labor market regulation, construction permission, access to electricity, property registration, access to credit, to protect minority investors, cross-border trade, tax, contract enforcement, deal with bankruptcy, etc. They cover the entire life cycle including the enterprise to create, access to sites, financing, daily operation, etc. Among them, setting up an enterprise mainly investigates the procedures, time, cost and minimum paid-in capital of setting up a limited liability company. Applying for a construction permit mainly investigates the quantity, time and cost of all procedures for completing the construction of the warehouse, as well as the quality control and safety mechanism in the construction permit

ISSN: 0010-8189

(C) CONVERTER 2020 
system. Access to electricity mainly includes the procedures, time and cost of connecting to the grid, the reliability of the electricity supply and the transparency of the electricity charges. The registered property mainly includes the procedures, time and cost of land transfer and the quality of the land management system. Access to credit includes chattel mortgage law and credit information system. The protection of minority investors mainly includes the rights of minority shareholders in related transactions and corporate governance. Tax payment mainly includes the number, time, total amount of tax payment and tax payment in the business process of complying with all tax laws and regulations, as well as the process after tax declaration. Cross-border trade mainly includes the time and cost of exporting products with relative advantages and importing auto parts. The execution of the contract mainly includes the time and cost of settling the commercial dispute and the quality of performing the judicial proceedings. Bankruptcy includes the timing, cost, outcome and recovery rate of commercial bankruptcy, as well as the strength of the bankruptcy legal framework. Labor market regulation mainly includes the flexibility of employment regulation and various aspects of work quality.

\subsection{Environmental factors:}

Political environment factors: policy stability, blurry boundary between government and market, government playing the role of both referee and athlete, etc. Economic environment factors: such as labor cost, unbalanced regional development, unreasonable industrial structure, etc. Investment environment factors: implicit market access threshold and exit barriers, etc. Foreign trade environment problems: barriers of personnel flow, convenience of foreign exchange management, etc. Administrative and legal environment factors: the efficiency of government operation, corruption of officials, the arbitrariness of power rent-seeking and law enforcement, the cost of protecting intellectual property rights, the level of intellectual property protection, etc. Cultural environment factors: whether the socialist market economy system market consciousness is weak; Natural environment problems: geographical conditions, climatic conditions, air pollution, etc.

Table 1: assessment indicators of business environment from the perspective of private enterprises

\begin{tabular}{|l|l|}
\hline Primary indicators & Second indicators \\
\hline Market convenience & Starting a business \\
\cline { 2 - 3 } & Apply for construction permit \\
\cline { 2 - 3 } & Get the electric power \\
\cline { 2 - 3 } & Registration of property \\
\cline { 2 - 3 } & Access to credit \\
\cline { 2 - 3 } & Protecting minority investors \\
\cline { 2 - 3 } & Tax payment \\
\cline { 2 - 3 } & Cross-border trade \\
\hline & Execution of contract \\
\hline Environmental factors & Political environment factors \\
\hline & Economic environment factor \\
\hline
\end{tabular}

ISSN: 0010-8189 


\begin{tabular}{|l|l|}
\hline \multirow{2}{*}{} & Investment environment factors \\
\cline { 2 - 3 } & Foreign trade environment factors \\
\cline { 2 - 2 } & Administrative and legal environmental factors \\
\cline { 2 - 2 } & Human environment factors \\
\cline { 2 - 2 } & Natural environmental factors \\
\hline
\end{tabular}

\section{The effect and significance of the establishment of business environment assessment indicators from the perspective of private enterprises}

The discussion of business environment is a worldwide topic. However, due to the different policies and systems of different countries and regions, different stages of development, diverse types of enterprises and large scope of involvement, there is no strict unified system for the construction and evaluation of the business environment. The evaluation index of business environment from the perspective of private enterprises is constructed from two aspects of market convenience and environmental factors. The objective is to evaluate the development status of private enterprises in terms of infrastructure construction, innovative resources, property rights protection, operating costs, government convenience and life maturity. Through the comparison of the index data, the imbalance of development between regions can be found. Conducting a comprehensive assessment of the business environment governance capacity in specific regions and comparing it with other regions is to find the problems in the business environment in the region. In view of the problem, put forward the corresponding feasible countermeasures and suggestions. These suggestions provide reference for the government to evaluate, manage and improve the business environment, and provide intellectual support for improving the business environment and driving economic growth.

\section{References}

[1] Jie Li, "Review and prospect of the study on the evaluation index system of business environment," Contemporary economics, no. 7, pp. 88, 2019.

[2] Weihua Guo, Penghui Fan, "Research on building a business environment assessment system in line with China's national conditions," China price, no. 4, pp. 7, 2019.

[3] Hui Jiang, "Optimize the business environment and promote economic development in northeast China," Dalian cadre journal, no. 04, pp. 43-44, 2017.

[4] Shuyan Wei, Feng Sun, "Investment and business environment assessment and optimization measures in northeast China," Changbai academic journal, no. 06, pp. 90, 2017.

[5] Wenhong Sun, Ye Wang, "We will do our best to improve the business environment with good governance and good laws," Liaoning economics, no. 08, pp. 50, 2017.

[6] Xianggang Peng, Ran Ma, "To optimize for business environment in government affairs and construction of evaluation index system," Academic research, no. 11, pp. 07, 2018.

[7] Jingzhou $\mathrm{Wu}$, "The revitalization of northeast China should start from optimizing the business environment," Economic aspect, no. 01, pp. 31-35, 2017.

[8] Linlin Song, Chengxiang He, "Logic and path of decentralization reform from the perspective of optimizing business environment: analysis based on the World Bank business environment indicator system," China administration, no. 04, pp. 69, 2018. 